\title{
Judíos de Belchite en el denominado «Libro de la escribanía de don Federico de Aragón, conde de Luna» (1422-1425)*
}

\author{
Joaquín Aparici Martí \\ Universitat Jaume I, Castellón
}

\begin{abstract}
La ausencia de fuentes documentales locales no había permitido hasta ahora conocer con algún detalle la comunidad judía de Belchite situada en el Bajo Aragón. Con ayuda de un manuscrito que contiene un manual ordinario del notario Pere Capdevila, inicialmente atribuido a una inexistente «escribanía de Federico de Aragón, conde de Luna», conservado en el Archivo Histórico Municipal de Segorbe (Castellón), el autor logra documentar aspectos biográficos y las actividades de judíos que vivían en esta localidad aragonesa en la década de 1420. Algunos de estos judíos aparecen mencionados por el poeta Šelomó Bonafed, que años más tarde se asienta en Belchite.
\end{abstract}

Palabras Clave: Historia de los judíos; siglo XV; Aragón; Belchite; cultura notarial; Segorbe.

The Jews of Belchite in the So-Called "Notarial Notebook of Federico de Aragon, CounT OF LunA" (1422-1425).- The lack of documentary local sources has hindered until here our knowledge of the Jews of the Aragonese town of Belchite, belonging to the count of Luna. By using a manuscript notarial notebook -that had been inaccurately ascribed to a "seigniorial notary's office of Federico de Aragon"- preserved in the City Archives of Segorbe, the author identifies several Jews living in the town in the 1420s and provides mention of their activities. Some of these Jews are featured in the Hebrew poems by Šelomoh Bonafed, the author that will settle in Belchite two decades later.

KEYwords: Jewish History; $15^{\text {th }}$ century; Aragon; Belchite; Notarial Culture; Segorbe.

* La elaboración de este artículo se inserta en el el proyecto de investigación «La manufactura rural i els oficis artesans en les comarques septentrionals valencianes durant la baixa edat mitjana» (I + D Generalitat Valenciana, año 2009, renovación 2010), dir. Prof. Carles A. Rabassa i Vaquer. Agradezco a los evaluadores anónimos de Sefarad las oportunas correcciones y orientaciones realizadas, así como a Rafael Simón Abad, archivero titular del Archivo Municipal de Segorbe, su amabilidad a la hora de consultar el manuscrito.

***japarici@his.uji.es 
Federico de Aragón, conde de Luna, nieto del rey Martín el Humano e hijo de Martín el Joven, rey de Sicilia, fue uno de los candidatos a ocupar el trono de la Corona de Aragón tras los óbitos de su padre, primero, y su abuelo, después. Desestimado rápidamente en el Compromiso de Caspe por su minoría de edad y por ser hijo ilegítimo, tras la entronización de Fernando de Antequera (1412), Federico reconoce al nuevo monarca y a su hijo Alfonso como heredero, pasando a estar bajo la tutela de la nueva dinastía, vinculándose especialmente con este último y participando activamente en su política italiana (manteniendo, al menos, sus aspiraciones a ocupar el trono de Sicilia), y al que acompaña en las acciones contra Castilla. En este empeño militar, Federico dilapidará su fortuna cargando de censales las tierras heredadas que formaban parte del antiguo patrimonio de María de Luna. Al final, agotados sus recursos, sin perspectiva de obtener un puesto destacado en la corte de Alfonso el Magnánimo, y sin un matrimonio estratégico conveniente, Federico optará por ayudar al rey de Castilla contra aquel, siendo desposeído en 1430 de su dominios en la Corona de Aragón. Poco después, el rey castellano lo encerrará hasta su muerte en 1434.

Como indicara Francisco de Moxó en el Congreso de la Corona de Aragón celebrado en Valencia en 2004, la figura de Federico merece un estudio más profundo. Se han hecho aproximaciones muy interesantes a través de las rentas obtenidas en sus dominios, y al proceso de endeudamiento crónico a que sometió su patrimonio valenciano y aragonés, o también a la situación bajo su señorío de una población concreta, Alcoy ${ }^{1}$. En esta ocasión, nos vamos a centrar en las informaciones acerca de judíos aragoneses entre 1422 y 1425 que se contienen en los documentos contenidos en un manuscrito conservado en el Archivo Histórico Municipal de Segorbe (Castellón)², ciudad de la que Federico era señor.

${ }^{1}$ Francisco DE Moxó, «Un linaje aragonés con proyección mediterránea: los Luna. Cauces abiertos de investigación», en XVIII Congrés d'Història de la Corona d'Aragó (Valencia 2005), vol. I, págs. 275-284; Francisco J. Cervantes Peris, La herencia de María de Luna. Una empresa feudal en el tardomedievo valenciano (Segorbe 1998); Carlos LALIENA, «Señoríos en una era de crisis. Los dominios de las casas de Luna e Híjar en la tierra de Belchite (Zaragoza), 13601450», Revista d'Història Medieval 8 (1998), págs. 175-216; y Ricard Bañó ARMiÑANA, Alcoi durant el senyoriu de Frederic d'Aragó, comte de Luna (1409-1430) (tesis de licenciatura inédita, Universidad de Alicante, 1985).

${ }^{2}$ F. José Guerrero Carot, Archivo Histórico Municipal de Segorbe (1286-1910) (Valencia 1986). Con la signatura 215 aparece catalogado de manera inexacta como «Libro de la escribanía de don Federico de Aragón, conde de Luna», papel (295 x 225 mm), 208 ff. más 10 hojas en blanco. Foliado por una mano posterior en lápiz. Cubierta de pergamino. El texto aparece escrito en valenciano (actos consignados en el reino de Valencia), castellano-aragonés (preferentemente, los actos consignados en Aragón), y también en latín (en ambos territorios). Las fechas extremas del manuscrito abarcan desde el 31 de julio de 1420 al 13 de diciembre de 1425 a excepción de 
El manuscrito no es un libro de contabilidad propiamente dicho, con entradas y salidas («dates e reebudes») ${ }^{3}$, y tiene la apariencia formal de un protocolo notarial, redactado por Pere de Capdevila. Pese a su título, el libro es un manual ordinario de un notario, ya que la «escribanía del conde de Luna» nunca existió como tal. Incluso, algunos documentos están autorizados en lugares que no eran del conde (como Burjassot), por lo que se trataría de un notario por autoridad real. Con todo, la documentación contenida en el manuscrito tiene como punto focal, de una u otra manera, la persona o los intereses de Federico de Aragón. Así pues, por ejemplo, localizamos el nombramiento y pago de salarios de alcaides - «a costum d'Espanya»- para varios castillos aragoneses como Erla y Arándiga, entre otros, y el pago de las reparaciones efectuadas en torres y muros, etc. Figura también el extenso listado de todas aquellas personas (y la aportación de rocines) que se inscribían en la compañía subvencionada por el rey a través de Federico, para la campaña de 1425 contra Castilla. Localizamos a su vez el arriendo de las rentas de algunos de los lugares del señorío, como Bureta, Pedrola, etc., o la entrega de las pechas correspondientes. También se documenta la acuciante necesidad de obtener crédito (censales) en los diversos lugares y villas del señorío. A su vez, son abundantes las procuraciones, tanto del conde a favor de ciertos nobles y familiares para, por él, asistir a Cortes, como por parte de individuos que forman parte de su Casa. Con todo, la documentación más reiterada es la entrega, graciosa o no, pues no se indica, de ciertas cantidades de dinero a todos los miembros de la Casa de Federico, con pagos a escuderos, escribano, halconero, sastre, platero, cocinero, etc., así como pagos efectuados por los receptores generales del conde -Bernat Medina en Valencia, y Açach Avendino en Aragón- al comprador o al administrador del dinero de Federico, para sufragar los diversos gastos que, mes a mes, se configuran. También cuando se habla de «capleutas», todos los presos están detenidos en las prisiones del conde.

Ciertamente, aparecen algunos testamentos y otros documentos contratados entre particulares, aunque siempre en estrecha relación con Federico. Así, el testamento del turolense Francisco Garcés, redactado en diciembre de 1420 en el castillo de Bonifacio (Córcega), pues dicho Francisco pudo ser uno de los soldados o acompañantes de Federico en esa primera campaña italiana. $\mathrm{O}$

un folio suelto datado en 1427 en el interior de manuscrito, que contiene el inventario de plata del Conde (entre ff. 164-165). La otra única referencia a 1427 procede de una anotación marginal que indica la cancelación de una comanda de 1425 en la que participan judíos (f. ${ }^{\circ} 2072$ ).

${ }^{3}$ Véase Joaquín Aparici Martí, «De domo dicti domini comitis. Aproximación a la corte señorial de Federico de Aragón, conde de Luna (1412-1425)», Aragón en la Edad Media (en prensa). 
el inventario de bienes del difunto maestre Francesc Granollach, el médico que, al menos desde 1411, acompañaba a Federico. O bien, una venta de casas de un mudéjar huido o fallecido sin descendencia, hecha por los diputados por el conde a tal efecto, pues los bienes del mudéjar habían revertido a este. Se incluye también el inventario de la vajilla de plata del conde en determinados momentos.

El notario Pere de Capdevila parece ser el redactor del manuscrito entre 1420 y 1425 . Pere ya aparecía como «escrivà de manament» en la corte del conde de Luna en $1411^{4}$. A lo largo de los folios del manuscrito, Pere figura como redactor de algunos textos (de los otros no se indica redactor). Así, los primeros documentos recogidos en el manuscrito se datan en noviembre y diciembre de 1420, mientras se realizaba la campaña en Córcega y Cerdeña. Después, en el deambular del conde por diversos lugares de Valencia y Aragón, el notario está presente explícitamente en algunos textos. Sólo la documentación deja un vacío cronológico en el manuscrito que hace pensar que ni Pere, ni otro notario, estuvieron al lado de Federico. Este vacío se corresponde con el período que va desde agosto de 1423 a enero de 1424, momento que coincide con la nueva campaña de Federico en Italia. Todo ello induce a pensar que la carrera profesional de Pere estuvo vinculada, al menos en parte, al servicio del conde, a quien posiblemente acompañaba, y para quien redactaba los documentos ${ }^{5}$. Y ello durante el período posterior

\footnotetext{
${ }^{4}$ Cf. Cervantes Peris, La herencia de María de Luna, pág. 227.

${ }^{5}$ En 1424 Çahat Mogí, alias Potorri, mudéjar de Segorbe, reconocía que Açach Avendino le había pagado 32 ss 10 dd jaqueses, que son 35 ss de Valencia, «por razón que he portado con mi bestia el officio de la scrivania del dito senyor comte, de la dita ciutat de Sogorve a la villa de Belxit» (13-I-1424, Belchite). Aunque se habla explícitamente de una escribanía, el oficio de Pere de Capdevila figura en el manuscrito bajo diversas nomenclaturas, así «secretario dicti domini comitis et regia auctoritate notario publico per totam terram et dominacionem serenissimi domini regis Aragone» en la redacción de los capítulos de la Receptoría General de Aragón; como «secretari del dit senyor comte», redactando un documento con una orden para el alamín de Bureta (22-IV-1422, Castillo de Burjassot, y 27-XI, Ainzón). O el más llamativo, «scrivà del senyor rey e secretari del dit senyor comte», cuando envió a Berenguer Minguet, consejero real, maestre racional de Valencia, y oidor asignado a las cuentas del conde de Luna, la certificación de Bernat de Medina como a receptor general en el Reino de Valencia (13-III-1421, s. 1.), por tanto, vinculación de Pere con el rey y con el conde a través de su oficio. En el manuscrito figura también otro Pere (Perico) de Capdevila, «menor de días», scriptor, escribent, tal vez hijo del anterior, que seguía los pasos profesionales de su padre, y que recibe una donación de 800 florines en el testamento del conde (1423). Después figura como testigo en varios actos (13-VIII-1423, Barcelona; 14-X-1425, Ainzón y 13-XII-1425, Segorbe). Un Pere de Capdevila aparece actuando como justicia de Segorbe en 1441 (AMS, asig. just. n. ${ }^{\circ}$ 122). También Pere de Capdevila actúa como scrivà de tresoreria, de l'offici de tresoreria, comissari de Principat citra et ultra, o tresorer
} 
al compromiso de Caspe, cuando Federico mantenía su fidelidad al rey aragonés.

El manuscrito permite rastrear el itinerario de una Casa señorial en continuo desplazamiento por sus posesiones en Valencia y Aragón. Por ello, y aún cuando el libro inicia la documentación en 1420, no es hasta 1422 -momento en que la Casa itinerante llega a tierras aragonesas-cuando se descubre la presencia de judíos entre los individuos mencionados en el mismo ${ }^{6}$.

\section{JudíOS EN BeLCHITE}

El manuscrito estudiado conservado en Segorbe permite la identificación de hasta 44 judíos, entre los que destacan aquellos que dicen habitar la villa de Belchite (20 del conjunto). Precisamente esta villa carece de fondos históricos locales para la aproximación al período medieval, y cualquier acercamiento procede de fuentes dispersas existentes en otros archivos ${ }^{7}$.

El hecho de una mayor presencia de judíos de Belchite en este manuscrito se debe, precisamente, a que allí se estableció el conde durante largos períodos, de la misma manera que, cuando estaba en Valencia, este se alojaba, preferentemente, en Benaguasil y la Pobla Vallbona, y, especialmente, en Segorbe. Por otro lado, la mención a siete judíos de Arándiga se debe a que en esos

del senyor rey entre 1445 y 1448. Un Pere Capdevila, notario de Valencia (tal vez él mismo, o más probablemente, por la edad, Pere, el menor), fue designado en abril de 1447 por el rey Alfonso baile de Penàguila en la baronía de Alcoy, ocupando dicho cargo hasta su muerte (fines de 1483 o inicios de 1484). El progresivo deterioro de su gestión induce a pensar en un prolongado absentismo en Penàguila, especialmente a partir de los años 70, cuando hay abundantes confusiones y equívocos en las cuentas y nóminas referidas a los enfiteutas que controlan las regalías de la corona, cf. Germán NaVARro EsPinACH - David Igual Luís, La tesorería general y los banqueros de Alfonso V el Magnánimo (Castellón de la Plana 2002), pág. 216; Antonio J. MiRA JódAR, Entre la renta y el impuesto: fiscalidad, finanzas y crecimiento económico en las villas reales del sur valenciano (siglos XIV-XV) ([Valencia] 2005), págs. 148 y 196-197.

${ }^{6}$ Por ello mismo, a partir de aquí obviamos la referencia documental de aquellas noticias alusivas a los judíos documentados en el manuscrito por cuanto todas ellas quedan recopiladas en la nómina final del artículo.

${ }^{7}$ Asunción Blasco MartínEZ, «El archivo Histórico de Belchite. Fondos notarial, parroquial y municipal», Cuadernos de Historia Jerónimo Zurita 45-46 (1983), págs. 167-236; EAD., «El fondo notarial de Belchite», en Comarca de Campo de Belchite (2010), págs. 130-132. El protocolo notarial más antiguo que menciona data de 1558. También de ese siglo proceden los primeros documentos parroquiales conservados, mientras que la documentación municipal se inicia en el siglo XVII, siendo más abundante para el XIX. 
momentos el conde y el notario estaban en dicho lugar. Recordemos que las posesiones de Federico en Aragón -el condado de Luna-, se podían agrupar en tres áreas preferentes: la zona de las Cinco Villas y Somontano oscense, el curso alto del río Aguasvivas, y el entorno del Campo de Belchite. De la primera sobresalía como cabecera la villa de Luna, seguida de Bolea, Erla, Biel (con una importante comunidad judía), etc. El segundo conjunto cohesionado de posesiones tuvo a Huesa como cabecera, junto a Blesa, Muniesa y Segura. Finalmente, la propia villa de Belchite, con Puebla de Albortón, Lécera, Almonacid de la Cuba, etc. .

Nuestra aproximación se centra en unos años muy concretos de la década de los veinte del siglo XV, período que dispone con una menor producción bibliográfica, por lo que podría llenar un vacío bibliográfico sobre Belchite en general, y sus habitantes judíos en particular, por cuanto los judíos de otras poblaciones aragonesas cuentan ya con extensos estudios, como es el caso de Arándiga ${ }^{9}$. Precisamente, la identificación de siete judíos de esta última localidad permite completar aspectos de los trabajos previos (Jacob y Jafudá Cariello). A su vez hay que indicar que también recogemos datos sobre judíos de Zaragoza (5), Pedrola (3), Luna (3), Borja (1), Huesa (1), además de otros (4) cuya localidad de origen no hemos podido identificar.

Acerca de los judíos de Belchite disponemos de unas anotaciones generales realizadas por Miguel A. Motis Dolader ${ }^{10}$, según el cual los judíos (salvo excepciones) no estaban sujetos al impuesto del «morabatín», de modo que no constan en las nóminas elaboradas en 1373 y 1427, al contrario que el pago de la «pecha», que sí les afectaba. Tomando las contribuciones de cada grupo, durante el primer tercio del siglo $\mathrm{XV}$, los cristianos de Belchite pagaban 550 ss jaqueses $(51,23 \%)$, los mudéjares 406 ss $(41,60 \%)$,

${ }^{8}$ Véase José A. Sesma - Juan Abella, «La población del Reino de Aragón según el fogaje de 1405», en La población de Aragón en la Edad Media (siglos XIII-XV). Estudios de demografía histórica (Zaragoza 2004), págs. 115-164.

${ }^{9}$ Encarnación MARín PADILLA, «La villa de Arándiga, del señorío de los Martínez de Luna, en el siglo xv: sus judíos», Sefarad 57 (1997), págs. 69-95 y 277-306; 58 (1998), págs. 277-298; 59 (1999), págs. 101-125 y 319-342; 60 (2000), págs. 127-142.

${ }^{10}$ Miguel A. Motis Dolader, «Mudéjares, judíos y cristianos nuevos en Campo de Belchite durante la Edad Media», en Comarca de Campo de Belchite (2010), págs. 99-112. Desafortunadamente, por su naturaleza, dicha publicación no ofrece referencias documentales a pie de página. También sabemos que en Belchite residió Šelomó Bonafed, poeta y polemista que, tras criticar a los miembros de la aljama zaragozana, tuvo que huir y refugiarse en diversos lugares, entre ellos Belchite, desde donde escribió ca. 1445 su opúsculo satírico contra los representantes de la aljama, cf. Eleazar GutwIRTH, «Social Criticism in Bonafed's Invective and its Historical Background», Sefarad 45 (1985), págs. 23-53. 
y los judíos 70 ss $(7,17 \%)$. Por esos mismos años, pagaban el «morabatín» 152 cristianos y 123 mudéjares, por lo que el número de judíos contribuyentes de la «pecha» no superaría en mucho dos decenas. Este autor ofrece un listado de 25 judíos de Belchite que identifica como acreedores de la comunidad mudéjar durante el reinado de Alfonso el Magnánimo".

Según el mismo autor, durante ese primer tercio del siglo XV se produjeron en Belchite conflictos entre algunos judíos (algunos prestamistas) y la comunidad mudéjar, con motivo de la insolvencia crediticia de estos últimos, materializados en el asalto y robo a algunos judíos, entre ellos Zacarías Abnarrabí, que dijo que había perdido durante los disturbios numerosos documentos de crédito. En estas primeras décadas se conmina a los judíos a circunscribir su barrio en torno a la sinagoga, por una orden real de marzo de 1415. Con anterioridad, las distintas comunidades de Belchite habían debido abonar en 1404 una multa que obligaba al pago de 150 florines a los mudéjares, 350 a los cristianos, y 100 a los judíos, por delitos efectuados «axí concellalment com singular».

\section{TIPOLOGIA DOCUMENTAL Y ACTIVIDADES DE LOS JUDÍOS}

La tipología de los actos en los que aparecen estos judíos es muy variada y nos permite hacernos una idea de alguna de sus actividades. En muchos casos sólo disponemos de noticias que nos informan de su actuación como testigos en actos notariales. Aún así, estos casos nos proporcionan información sobre la onomástica y ubicación geográfica del judío, pues está presente, como testigo, en el lugar donde se redacta el documento, lo que ofrece información sobre su movilidad por razón de negocios o por motivos familiares, etc. Por ejemplo, Mahir Abnuba, de Belchite, estaba en el castillo de Burjassot (Valencia) en 1422, cuando Açach Avendino recibía los capítulos de la Receptoría General del conde en Aragón.

${ }^{11}$ Algunos de ellos aparecen con algunas diferencias de onomástica en la nómina final de este artículo. A excepción de uno, del que dudamos si identificarlo como «mayor» o «menor», los judíos que coinciden en ambos listados están marcados con una (X): Açach Avendino (X), Mossé Avendino, Ezmel Avendino, Zecrí Avendino, Samuel Cidez, el mayor (¿?), Samuel Cidez, el menor, Zulema Cidez, el mayor, Zulema Cidez, el menor (X), Mossé Penya, Mossé Abenba, Jucé Abenba, Mahir Abenba (X), Jacó Abenbarbes, Jucé Aninuha, Bahiel Abenpesat (X), Jahudá Abenpesat (X), Vidal Bitón, Jahudá Bitón, Jehudá Abulfeda, Jucé Bahalull, Gentó Bahalull, Azarías Abnarrabí (X), Zulema Neyello y Mossé Çucrán (X). Si a los 20 judíos de Belchite que aparecen mencionados en este artículo le restamos 8 nombres (mencionados por Motis) y sumamos sus 25 nos da una cifra de 37 judíos identificados durante el primer tercio del XV.

${ }^{12}$ LaLiena, «Señoríos en una era de crisis», págs. 200-201. 
Zecrí Abenabez, de Belchite, se desplaza -en calidad de procurador de Açach Avendino- hasta Ainzón para percibir de manos de los jurados del lugar la «peita» ordinaria correspondiente a la paga de San Miguel de 1425.

Resulta significativo que del conjunto de judíos que hemos recabado, sólo en dos ocasiones se menciona una profesión específica, en ambos casos vinculada a la atención de la salud. El médico del conde de Luna, Francesc Granollach, había fallecido poco antes del 7 de octubre de 1422 (f. ${ }^{\circ}$ 51r). Este profesional formaba parte de la corte o séquito del citado noble ya en 1411, cuando percibía un salario diario de 2 ss y, por tanto, era una persona reconocida cuya presencia al lado de Federico de Aragón debía ser constante $^{13}$. Una vez finado, y ante la eventualidad de una urgencia médica, el conde no duda en buscar soluciones, más o menos transitorias. Así, en febrero de 1423, Guillem de Entreviesa, vecino de Peñaroyas, reconoció que Açach Avendino, como receptor general del conde en Aragón, le había pagado 4 florines para ir desde ese lugar hasta Belchite, «e por tornar e endreçar el braço de Guillem Arnau, scudero del dito senyor comte, que tenia sacado de lugar» ${ }^{14}$.

Sin embargo, será maestre rabí Senyhor, físico / «metge» de Belchite, el requerido en más de una ocasión para tratar a los enfermos de la Casa condal, lo que induce a pensar en su reconocimiento profesional. En marzo de 1423 curaba a Francés Ros y a Joan de Sent Adriá, escuderos del conde, «estando malautos en la present villa de Belxit». Días más tarde, en abril, percibe su salario por haber atendido al camarlengo del conde, el caballero mosén Ramón Boil. Y en mayo recibe 10 florines como salario por sus trabajos «de visitar e curar» a mosén Luís Çabata, Joan Medina y Francés Ros, todos escuderos del conde. Meses después, en febrero de 1424, recibe otros 4 florines por haber curado a Simonet, uno de los pajes del conde, además de otra cantidad, por orden expresa del conde, a fin de sufragar el dispendio realizado en vestuario. A él podemos añadir otro judío médico en Belchite, Ismell Abennaçar, llamado «cirurgicus» en $1424^{15}$.

\footnotetext{
${ }^{13}$ Cervantes Peris, La herencia de María de Luna, pág. 226.

${ }^{14}$ 15-II-1423, Belchite.

${ }^{15}$ Véase, entre otros, Asunción Blasco Martínez, «Médicos y pacientes de las tres religiones (Zaragoza siglo XIV y comienzos del XV)», Aragón en la Edad Media 12 (1995), págs. 153182; José Hinojosa Montalvo, «Médicos judíos en la ciudad de Valencia en la Baja Edad Media», en Estudos em Homenagem ao professor doutor José Marques (Porto 2006), págs. 415437; Mercedes GaLlent Marco, «Licencias reales para ejercer la medicina y cirugía a judíos aragoneses», Revista de Historia Medieval [= Anales de la Universidad de Alicante. Historia Medieval] 15 (2006-2008), págs. 47-56.
} 
La propia naturaleza de la documentación nos presenta una realidad indudablemente fragmentaria. Así, no encontramos ninguna referencia a actividades artesanales de los judíos, lo que no quiere decir que no hubiera judíos dedicados a esos menesteres, y son muy parcas las referencias a las propiedades agrarias de estos ${ }^{16}$.

Por lo que respecta al comercio de mercancías, sólo un documento de 1423 nos informa que Açach Avendino se obligaba a proporcionar pieles de macho cabrío, cabra y sebo, a dos judíos zaragozanos. Sin embargo, la mayoría de las noticias se refieren a actividades crediticias, a través de comandas-depósito o mediante el arrendamiento de rentas de determinados lugares, etc.. En general, las actividades de prestador, arrendador, recaudador de impuestos, etc., contribuyeron a acentuar determinados clisés negativos.

Así, Abraham Abiayú, judío de Zaragoza, aparece como arrendatario, junto al mudéjar Hamet de Zuleyma, alamín de Bardallur, de las rentas pertenecientes al conde en los lugares de Bardallur, Turbena y en la mitad de Plasencia, en 1422. Jucé Axeuill, judío de Borja, tomaba en arriendo las rentas pertenecientes al conde de Luna en el lugar de Bureta, por espacio de 4 años ${ }^{17}$. Gentó Alborge, judío de Pedrola, tomaba en 1423 en arriendo junto a Simó de Setembre, escribano de ración de Casa del conde, las salinas de sal de compás de Pedrola, por

${ }^{16}$ En Segorbe, del señorío de Federico de Aragón, los judíos que han podido ser documentados se dedicaban preferentemente a actividades como la platería y la correduría. Las menciones a propiedades inmuebles vinculadas con el cultivo (cereal y viña principalmente) no permiten establecer un trabajo directo sobre las mismas de estos judíos segorbinos, sino más bien la posibilidad de que las arrendaran a campesinos, véase Joaquín ApARICI MARTí, «Judeo-conversos en Segorbe. Actividad secundaria y terciaria en el siglo XV», Instituto de Cultura del Alto Palancia 8 (1999), págs. 57-78. Marín Padilla indica que los judíos eran casi autosuficientes en Arándiga para cubrir sus necesidades, con varios prestadores, un médico, un albardero, dos zapateros, un pellejero, un tejedor, dos carniceros y un platero, cubriendo el resto de necesidades con profesionales mudéjares. Menciona además la propiedad de algunas parcelas de viña y majuelo, de olivar, etc. (cf. MARín PaDILla, «La villa de Arándiga», pág. 285). Sobre la posesión de viñedos por judíos, véase Juan PiQueras HaBA, «Los judíos y el vino en España, siglos XI-XV. Una geografía histórica», Cuadernos de Geografía de la Universitat de València 75 (2004), págs. 17-41. En el manuscrito ahora estudiado, sólo encontramos referencias a propiedades agrarias de judíos en la mención hecha en 1423, cuando el alamín de Pedrola, Jucé Abenamir, el mayor, toma en arriendo las rentas de dicho lugar, e indica «que sea partido el término de la aldea clamado del senyor, en quinyones», y que se reparta entre cristianos, mudéjares y judíos, a razón de 5 cahizadas por yugo; y también la mención a cierto problema suscitado entre García de Sesse, prior de la cofradía de San Martín, y Mossé Alatzar, de Belchite, respecto a 6 ss de «trehudo» que la cofradía reclamaba sobre el huerto que Alatzar había comprado de Johán Dossall, escudero habitante en dicho lugar (19-III y 29-IV-1423).

${ }^{17}$ En este caso en concreto se detallan algunas cuestiones del arriendo, que permitirán al judío el acceso directo a parte de la cosecha: «Si volrà partir en garba o fexos en los camps, que u puga fer. O si volrà en la era, que sia a sa elecció. Et que los moros le sian tenguts de pagar per les terres que han compradas jatsia que façan certs trehues del huyteno. $\mathrm{E}$ al affarraçar de las vinyas, hi haja dues personas, una per part del dit Jucé arrendador, e altra per part dels alamí e jurats». 
espacio de 2 años. Açach Francés, judío de Arándiga, sería arrendador de las rentas del conde en dicha población en 1424.

También hemos documentado algunas comandas monetarias ${ }^{18}$. En ellas, el prestatario reconoce que ha recibido del prestador una suma de dinero determinada, prometiendo devolverlo en un plazo específico de tiempo, y comprometiendo a cambio su propia persona y bienes, además de renunciar a toda acción judicial que pudiera ir contra lo estipulado y acuerda devolver aquella cantidad prestada en el plazo y lugar indicado en el documento. Sin embargo, debemos tener presente que tal acto no implica necesariamente un intercambio monetario, pues se trata en realidad de títulos de depósito de crédito.

Podemos suponer de antemano que el prestador es judío, como así ocurre en algún caso. En noviembre de 1425, Mahomat de Muça Febrer, alamín de Codo, reconoce tener en comanda y puro depósito de Açach Avendino, judío de Belchite, 55 florines, que devolverá cuando sea requerido. El acto se cancelaría en julio de 1427. Sin embargo, algunas de las comandas documentadas muestran aparentemente el fenómeno inverso, por el que el judío es el sujeto prestatario, tratándose, además, de cifras considerables, todas ellas entregadas por Federico de Aragón. En abril de 1423, Jafudá Cariello, judío de Arándiga confesaba tener en comanda del conde 2.000 florines, a devolver cuando este quisiese. También, Jucé Elisá, de Luna, confesaba en diciembre de 1422 tener 5.000 florines en comanda de Federico. Y Açach Francés, de Arándiga, jura junto a su esposa Caravida, en noviembre de 1425 tener 3.000 florines en puro depósito y comanda del conde. Puede tratarse de un mero formulismo acordado entre las partes, que oculta mediante un contrato de comanda, la entrega de un dinero en pago a una determinada deuda equivalente a esa misma suma monetaria ${ }^{19}$.

Contamos con otros detalles acerca de la actividad crediticia de los judíos belchitanos. Recordemos por ejemplo a Zacarías Abnarrabí, que según hemos mencionado antes había perdido numerosos documentos de crédito tras ciertos alborotos con los mudéjares en Belchite. Años más tarde, en 1453-1454, el

\footnotetext{
${ }^{18}$ María J. Roy MARín, «La comanda-depósito entre las minorías religiosas en la Zaragoza bajomedieval», Cuadernos de Historia Jerónimo Zurita 74 (1999), págs. 27-50.

${ }^{19}$ Aunque esto no lo hemos podido comprobar en el caso de los judíos, sí que se intuye en algún caso que implica a mudéjares. Así, en noviembre de 1425, Mahomat Serón, el alamín Mahomat Calavera, Mahomat Verdugo y Alí de Brea, mudéjares de Sabiñán, confesaban tener 50 florines en comanda de Miquel de la Torre, vecino de Belchite. A continuación, Mahomat Serón confesaba haber llegado a un acuerdo con Açach Avendino para poder salir de la prisión del conde, donde estaba retenido por ciertos delitos, precisamente abonando esa misma cantidad (22XI-1425, Belchite). Es cierto que se trata de una suma inferior a las mencionadas, y desconocemos a qué obedece dicha cantidad. No podemos olvidar que el conde había dilapidado su patrimonio con el cargo de censales, y que precisamente en 1425 se preparaba la campaña contra Castilla.
} 
concejo de Alcaine reconocía deber al judío de Belchite Azail Arribas, 207 ss jaqueses; y el judío de Belchite Bachiel Abenpesat mantenía cierto pleito con el alamín de la aljama mudéjar de Letux, por cuanto aquel pretendía embargar una tierra dada como fianza o garantía de un préstamo que no se había satisfecho. Caso diferente es el de Açach Avendino, receptor general del conde de Luna, que tras la confiscación del condado por el monarca, pasaron a manos de la reina María Belchite, Almonacid de la Cuba y Puebla de Albortón con toda su jurisdicción, derechos y vasallos (28-V-1431). Poco después, a fines de agosto, la reina autorizaba a Açach a percibir una parte de lo que pudiera quedar de los ingresos señoriales para resarcirle de un préstamo de 400 florines que anteriormente le había hecho ${ }^{20}$.

\section{NÓMINA DE JUDÍOS DOCUMENTADOS}

1. Abenabez, Zecrí / Zegrí. Judío de Belchite (1423-1425). Testigo en acto notarial en Belchite, y el último en Bureta (19 y 28-II-1423; 25 y 30-IV, f. ${ }^{\circ}$ 63r, 72r, 81v; 8-II-1424, f. $109 v$; 15-X-1425, f. ${ }^{o}$ 200r). Anequí de Bues, halconero de origen alemán, reconoce que Zecrí le ha pagado por orden del conde 80 florines por 2 halcones (13-IV-1425, f. ${ }^{\circ}$ 158r). Actúa como procurador de Açach Avendino en calidad de receptor de las rentas del conde de Luna, según documento notarial fechado el 10-X-1425, por el notario de Belchite Gómez de Pueyo. Merced a él, reconoce que los jurados de Aynçón le han pagado los 1.050 ss jaqueses de peita ordinaria de la paga de San Miguel. Acto en Aynçón (14-X-1425, f. ' 199v).

2. Abenaçot, Jafudá. Judío de Pedrola (1422). Testigo en acto notarial en Pedrola (26-X-1422, f. 53 r).

3. Abenarduth, Alatçar (1423). Testigo en acto notarial en Zaragoza (5-V1423 , f. 94 r) $)^{21}$.

${ }^{20}$ Manuel Gómez de VAlenzuela, «Ocho documentos sobre judíos del Bajo Aragón (14531454)», Aragón en la Edad Media 10-11 [= Homenaje a la Prof. Emérita María Luisa Ledesma Rubio] (1993), 373-384. El caso de Avendino aparece referido en LaLIENA, «Señoríos en una era de crisis», págs. 186-187.

${ }^{21}$ Es posible que se trate de Alazar Abenardut, hijo de Mossé y hermano de Jacob, documentado en 1392 como judío habitante en Zaragoza, y que figura en 1406 como pañero, cf. Asunción Blasco Martínez, «Judíos zaragozanos comerciantes de tejidos en el siglo XIV: anotaciones biográficas», Acta Historica et Archaeologica Mediaevalia 26 (2005), págs. 587-612: 589, n. 27 30; el «consellero» de la aljama de Zaragoza, Salamón, hijo de Alazar Abenardut, es mencionado en 1402, pero no tengo la seguridad de que se trate del mismo individuo, cf. Manuel SERRANO Y SANZ, Orígenes de la dominación española en América (Madrid 1918), pág. xvi. 
4. Abenbolat, Gentó. Judío de Huesa (1423). Testigo en acto notarial en Belchite (14-III y 12-IV-1423, f. ${ }^{\text {o }} 72 \mathrm{v}, 80 \mathrm{r}$ ).

5. Abencanyes, Salamó (1422); véase Jucé Alcastiell.

6. [ABEn MeIR] rabí Senyhor / Senihor. Maestre físico, judío de Belchite (142324). Recibe un salario de 6 florines por atender a dos escuderos del conde de Luna que estaban enfermos, además de otros 5 por atender a mosén Ramón Boil, camarlengo del conde. Algo más tarde, atiende a otros tres escuderos del conde, recibiendo 10 florines (18-III, 1-IV y 2-V-1423, f. $75 \mathrm{v}, 78 \mathrm{v}, 93 \mathrm{v})$. Al año siguiente recibe 23 florines y 2 ss jaqueses para cubrir el gasto en vestuario que le había ordenado el conde, además de otros 4 florines por la cura que hizo a Simonet, paje del conde (24-II-1424, f. $115 v$ ). Se trata del mismo rabí Seneor b. Meir, que otorga últimas voluntades en La Almunia de Doña Godina el 13 de abril de 1439. Entre las donaciones que efectúa se mencionan 5 florines para Isaac Carrillo, por algunos servicios que había prestado cuando estaba en Belchite, y el reparto de sus libros a los discípulos, entre ellos, Šelomó Costantiní ${ }^{22}$.

7. AbennaçAR, Ismell. «Cirurgicus», judío de Belchite (1424). Testigo en acto notarial en Belchite (21 y 31-I-1424, f. ${ }^{\text {o } 109 v, ~ 112 r) . ~}$

8. AbenPesat, Bayel / Bayell. Judío de Belchite (1423-1424). Testigo en acto notarial en Belchite (12-II-1423; 19-I-1424, f. ${ }^{\circ}$ 63r, 109v).

9. AbenPesat, Jaudá / Jahudá. Judío de Belchite (1423-1424). Testigo en acto notarial en Belchite (16 y 18-III-1423, f. $75 \mathrm{r}-\mathrm{v}$; 11-I-1424, f. ${ }^{\text {10 } 109 r) . ~ S e ~ m e n-~}$ ciona que era el «collidor de los bienes o dineros que fueron emparados como a bienes de Francisco Riera», antiguo receptor del conde de Luna, y que había sido destituido por irregularidades contables (30-IV-1423, f. ${ }^{\circ} 92 \mathrm{v}$ ).

10. Abiayú, Abraham. Judío de Zaragoza (1423). Açach Avendino, en nombre del conde, confiesa haber recibido de Hamet de Zuleyma, alamín de Bardallur, y de Abraham Abiayú, arrendadores de las rentas pertenecientes al conde en los lugares de Bardallur, Turbena y en la mitad de Plasencia, 5.300 ss jaqueses pertenecientes al año 1422 (1-III-1423, f. $70 \mathrm{v})^{23}$.

${ }^{22}$ Laura Minervini, Testi giudeospagnoli medievali. Castiglia e Aragona (Napoli 1992), vol. I, págs. 256-265.

${ }^{23}$ Podría identificarse con su homónimo mencionado por Bonafed, cf. Hayyim SchiRmann, «Ha-pulmus šel Šelomo Bonafed bi-nekbade Zaragoza», Kobez 'al Yad 4 [14] (1946), págs. 11-64: 25. Agradezco al Dr. Javier Castaño esta referencia, así como la transcripción de las suscripciones en aljamía hebraica que incluyo a continuación. 
11. Abinforma, Bitas (1422). Hijo de Salamó Abinforma; véase Jucé Alcastiell.

12. Abinforma, Salamó (1422). Padre de Bitas Abinforma; véase Jucé Alcastiell.

13. Abnarrabí, Abraham. Judío de Belchite (1424). Testigo en acto notarial en Belchite (24-II-1424, f. $115 \mathrm{v})$.

14. Abnarrabí, Azarías. Judío de Belchite (1423-1425). Testigo en acto notarial en Belchite (19-III-1423, f. ${ }^{\circ}$ 75v; 14-XI-1425, f. ${ }^{\circ}$ 202r).

15. Abnuba, Mahir. Judío de Belchite (1422-1425). Testigo en acto notarial, presente en el castillo de Burjassot (Valencia) (22-IV-1422, f.o 49r). Testigo en acto notarial en Belchite (23-II y $29-$ III-1423, f. ${ }^{\circ} 64 \mathrm{v}, 77 \mathrm{r}$; 21 y $24-\mathrm{II}-1424$, f. ${ }^{\circ} 115 v, 116 r ; 12,16,21$ y 27-XI-1425, f. ${ }^{o} 201 v, 202 v$, 205v). Junto a Samuel Cidez «capleva» la persona detenida en la corte del conde de Zuleyma Cidez, el menor, prometiendo restituirlo en tres días. Se cancela poco más tarde el 8 de febrero (19-I-1424, f. $\left.{ }^{\circ} 109 \mathrm{v}\right)$.

16. AbulfadA, Jucé. Judío de Belchite (1424). Testigo en acto notarial en Belchite (23-I-1424, f. ${ }^{\circ}$ 110r).

17. Alatçar / alaçar, Mossé. Judío de Belchite (1423). Testigo en acto notarial (21-III-1423, f. ${ }^{\circ} 76$ r; 8-VII-1427, f. ${ }^{\circ}$ 207r). Recibe 5 florines de gratificación de manos de Açach Avendino por cuanto consiguió «en el correr de las rentas de los moros de Belxit» que éstas pasasen de 5.010 a 5.100 ss jaqueses (27-IV-1423, f.o 91r). Surge cierta cuestión entre García de Sesse, prior de la cofradía de S. Martí, y Mossé, respecto a 6 ss de «trehudo» que la cofradía pedía al judío sobre el huerto que este había comprado a Joan Dossall, escudero habitante en Belchite (29-IV1423, f. ${ }^{\circ} 95$ r). Un día después, Joan Dossall, promete no hacer daño a Mossé Alaçar (30-IV-1423, f. $\left.{ }^{\circ} 93 \mathrm{v}\right)$. En 1431, junto a varios cristianos y mudéjares, debe constituir una garantía de 6.000 florines para asegurar que el alcaide del castillo de Belchite y otras tres personas, fieles a Federico, retornarían y se entregarían en prisión ${ }^{24}$.

${ }^{24}$ LALIENA, «Señoríos en una era de crisis», pág. 201, indica que «el rey hizo pagar caro los errores de los hombres fieles a Federico de Luna a sus parientes y amigos. Sancho Peirona, Antón y Domingo de Azuara, Salvador Ortín, Mose Alazar, Azac Arama, Juce de Ceine, Mahoma el Corral y Mahoma Lavata, tuvieron que constituir una garantía de seis mil florines para asegurar que el antiguo alcaide de Belchite y otras tres personas acusados que s'eran idos al olim Federico de Luna, antiguo conde por fer ciertos tratos, se entregarían en prisión. Como uno de los inculpados, Juan de Orduña, huyó, cayeron en la pena, que fue rebajada a 125 florines, de los cuales el monarca todavía les perdonó una quinta parte». Podría tratarse del mismo Mošé Alazar, patrón de Bonafed en Belchite, cf. SchIRMAnN, «Ha-pulmus šel Šelomo Bonafed bi-nekbade Zaragoza», págs. 35-36. 
18. Alborge, Gentó. Judío de Pedrola (1423). Junto con Simó de Setembre, escribano de ración de Casa del conde, recibe en arriendo de manos de Açach Avendino -como receptor general de los intereses del conde de Luna- las salinas de sal de compás de Pedrola, por 41 florines anuales, por espacio de 2 años (7-III-1423, f. ${ }^{\circ} 72$ r).

19. Alcastiell, Jucé. Judío de Pedrola (1422). «Manlevó» la persona cautiva de Bitas Abinforma, hijo de Salamó Abinforma, prometiendo satisfacer en tres días a Salamó Abincanyes lo que le adeudaba el cautivo (26-X-1422, f. ${ }^{\circ}$ 53r); véase adelante, doc. $\mathrm{n}^{\circ} 2$.

20. Argelet, Mossé. Judío de Luna (1422). Açaçh Avendino, como receptor general de las rentas del conde de Luna en Aragón, reconoce que los jurados y adelantados de la aljama de judíos de la villa de Luna, por mano de Mossé Argelet, le han entregado 25 florines para el pago del subsidio del quitamiento del presente mes; y 87 ss 6 dd jaqueses, parte proporcional que debían pagar en el donativo de 10.000 ss que hacía un año se había hecho al señor por todos los lugares y villas de su condado (27-X-1422, f. $\left.{ }^{\circ} 53 r\right)$.

21. Avendino, Açach. Judío de Belchite (1422-1427). Receptor general del conde de Luna en sus posesiones en el reino de Aragón. Es uno de los judíos más importantes mencionados en el manuscrito ${ }^{25}$. Los capítulos sobre su receptoría se consignan en el castillo de Burjassot en abril de 1422, estando presente Avendino. Destacan, entre otros, que tenga que rendir cuentas anualmente durante un período no superior a dos meses desde el final del año, y solamente en Belchite, Huesa o Zaragoza. Avendino jura «per dominum Deum et decem precepta legis Moyse, ad modum iudeorum» (22-IV-1422, f. ${ }^{\circ} 49$ r), véase adelante, doc. n. ${ }^{\circ}$ 1. Aparentemente vende a los judíos de Zaragoza, Mossé Nagerés y Zecrí Gallur «toda aquella corambre de cabrón que porrà haver», enviándola a Zaragoza, a razón de 34 ss 10 dd jaqueses la docena, si bien modifica el precio hasta los 36 ss 6 dd. También, todos los cueros de cabra, a 21 ss la docena, y el sebo a 31 ss 6 dd jaqueses el quintar (2-III-1423, f. 71 r). Mahomat de Muça Febrer, alamín de Codo, reconoce tener en comanda y puro depósito de Avendino, a título personal, 55 florines. Se canceló la comanda el 8 de julio de 1427 (29-XI-1425, f. $207 r$ ).

Por orden del conde, cierta cantidad de piezas de plata propiedad de Avendino habían sido encomendadas a Xerón, «reboster» del conde, para que fueran

\footnotetext{
${ }^{25}$ Serrano y Sanz, Orígenes de la dominación española en América, págs. 152 y ss., y 187, n. 4.
} 
pesadas por el almotacén de Belchite (15-XII-1427, folio suelto entre f. ${ }^{\circ} 164$ 165). En la cabecera del folio, aparecen dos líneas con anotaciones en aljamía hebraica con el siguiente texto (fig. 1):

פיישו איל ארג'ין ח' מארקוש אה אי ה' אונזאש וחצי, לוש קואליש איראן ח'

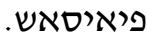

(«Pesó el argén 8 marcos e 5 onças va-ḥeși ['y media'], los quales eran 8 pieças»).

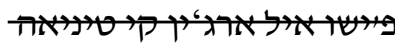

(«Pesó el argén que tenía»).

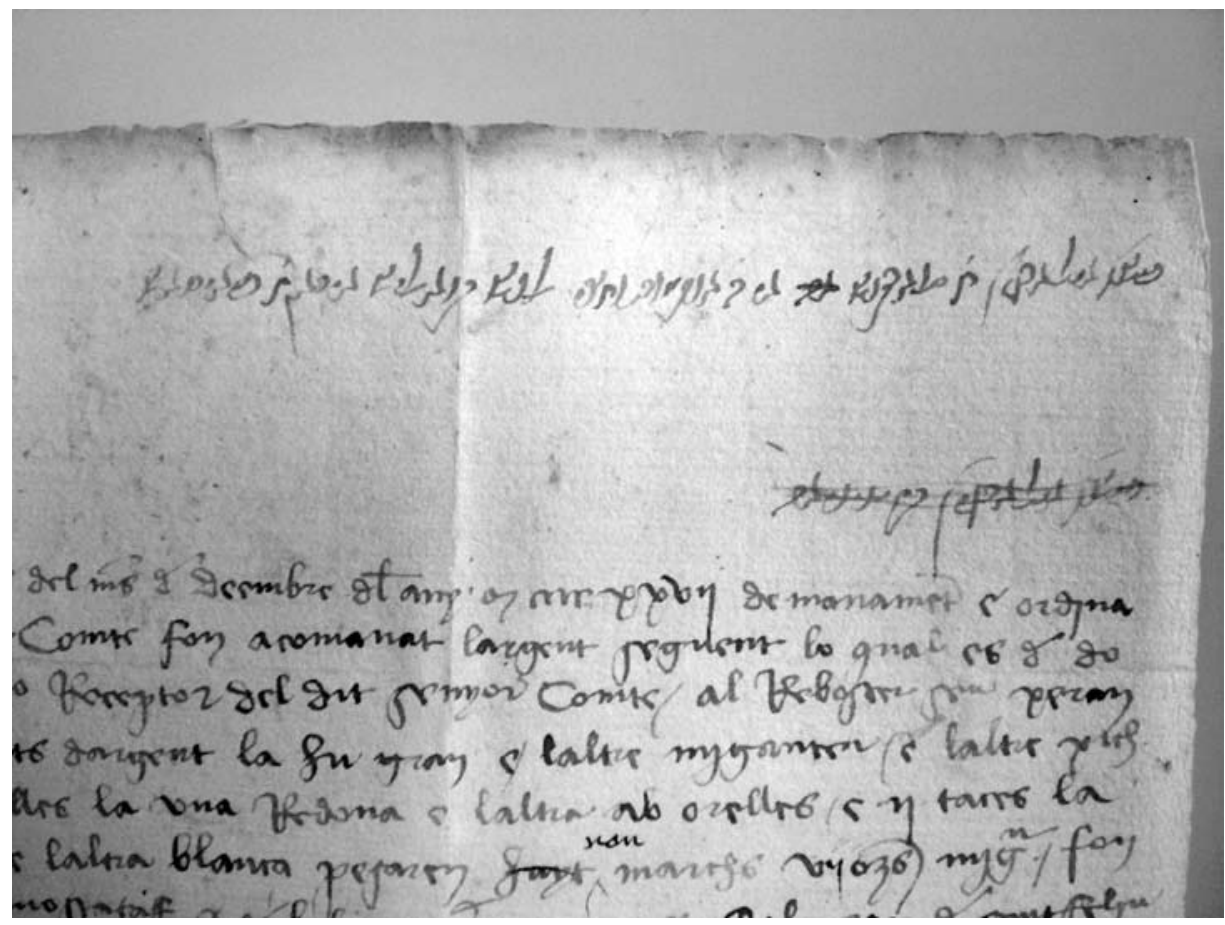

Fig. 1. Folio suelto entre f. ${ }^{\circ}$ 164-165: «Pesó el argén 8 marcos e 5 onças va-ḥeși ['y media'], los quales eran 8 pieças». 
22. Axeuill, Jucé. Judío de Borja (1423-1425). Estaba presente en Belchite, donde Açach Avendino le arrienda las rentas pertenecientes al conde de Luna en el lugar de Bureta, por 4 años, a 4.200 ss jaqueses anuales, pagaderos en dos mitades, el 1 de mayo y 1 de octubre. Ese lugar estaba poblado por mudéjares. Axeuill daba por fiador a Jucé Boxach, mudéjar del lugar. Un mes más tarde se revocaba el arriendo de las rentas de Bureta, haciéndose ahora a favor de Alí el Ferrero, mudéjar del lugar, por el mismo tiempo y cantidad (16-III y 25-IV-1423, f. 75 r, $81 v)$. Figurando como re-arrendador de las rentas del conde de Luna en el lugar de Bureta, Mahomat el Ferrero, Mahomat Cançalá, alias Carnicero, Jucé Boxach y Abdallá Obeix, jurados mudéjares del lugar, reconocían que Axeuill les había entregado por la paga de octubre 2.100 ss jaqueses (1.920 en contante y el resto en taras del molino harinero y precio de una muela que había comprado para el molino de dicho lugar (15-X-1425, f. ${ }^{\circ} 200$ r); véase adelante, doc. $n^{\circ} 4$.

23. AzÁn / AçÁn, Jucé. Judío de Arándiga (1424-1425). Aparece vinculado a Açach Francés en el pago del arriendo de las rentas de Arándiga (24-II-1424, f. 116r). Mencionado como testigo en un acto notarial (6-XI-1425, f. ${ }^{\circ}$ 200v). Interrogado como testigo sobre el robo de una serie de monedas perpetrado por Pedro de Huesa, en el hostal de ese lugar (7-XI-1425, folio suelto).

24. BAÇO, Abraham. Judío de Belchite (1425). Testigo en acto notarial en Belchite (29-XI-1425, f. ${ }^{\text {207v). }}$

25. Benbaca, rabí Abraham. Judío de Arándiga (1425). Su viuda Luna Cohena confiesa tener en comanda y puro depósito del conde de Luna 500 florines (8-XI-1425, Arándiga, f. o 201r); véase adelante, doc. no 5.

26. CARAvida. Esposa de Açach Francés, judíos de Arándiga (1425).

27. Cariello, Jacob. Judío de Arándiga (1425). Interrogado como testigo sobre el robo de una serie de monedas perpetrado por Pedro de Huesa, en el hostal de dicho lugar. El acto se realiza en el castillo de Arándiga (7-XI-1425, folio suelto) ${ }^{26}$.

28. CARIEllo, Jafudá. Judío de Arándiga (1423-1425). Junto a Açach Francés, judío del mismo lugar, se obliga a pagar al receptor del conde de Luna, 800 florines, la mitad en abril y la mitad en mayo, sin especificar el motivo. A continuación, Jafudá reconoce que la deuda le atañía sólo a él, y no a Açach. Dos

\footnotetext{
${ }^{26}$ Acerca de este individuo, Marín Padilla («La villa de Arándiga», passim) menciona varios individuos homónimos que pueden identificarse con este judío de Arándiga.
} 
días más tarde confesaba tener en comanda o puro depósito del conde de Luna 2.000 florines; acto realizado en Belchite (12 y 14-IV-1423, f. ${ }^{\circ} 80$ r). Aparece como testigo mencionado en un acto notarial realizado en Arándiga (8-XI-1425, f. ${ }^{\circ}$ 201r). De él sabemos que vivía en Arándiga desde 1403, finando en La Almunia de Doña Godina en 1450. Se conserva abundante documentación de su actividad crediticia ${ }^{27}$.

29. CAVAlLeria, Vidal de la. Judío de Zaragoza (1424), era el dirigente de los judíos de Aragón durante estos años. A petición del conde de Luna, el consejo y la aljama judía de Pedrola se obligaba en 660 florines con carta de comanda a Vidal, con asignación sobre la paga de las rentas de Pedrola del próximo mes de mayo, y para cumplimentar el total, también con las de Luceni (23-I-1424, f. ${ }^{\circ}$ 110r). Sabemos que este Vidal había sido delegado en 1417 junto al merino de Zaragoza Pardo Lacasta, para reformar la constitución por la que se regían los judíos de dicha ciudad. En 1422, la reina doña María había ordenado que le fueran entregados 250 florines para recompensar los servicios que, como representante de las aljamas del reino, había hecho en la corte pontificia ${ }^{28}$.

30. Cerruya, Benjamín. Judío de Belchite (1423). Testigo en un acto notarial en Belchite (21-III-1423, f. ${ }^{\circ}$ 76r).

31. Cidez, Mossé. Judío de Belchite (1425). Testigo en un acto notarial en Belchite (29-XI-1425, f. ${ }^{\text {2 } 207 r) . ~}$

32. Cidez, Samuel. Judío de Belchite (1424). Junto a Mahir Abnuba, «caplevan» de la corte del conde a Zuleyma Cidez, el menor, comprometiéndose a restituirlo en tres días. El acto se canceló el 8 de febrero (19-I-1424, f.o 109v).

33. Cidez, Zuleyma, el menor. Judío de Belchite (1424). Tras haber sido detenido en la corte del conde, era «caplevado» por Samuel Cidez y Mahir Abnuba, quienes se comprometían a restituirlo en tres días (19-I-1424, f.o 109v).

34. Cohena, Luna. Viuda de rabí Abraham Benbaca, judíos de Arándiga (1425).

${ }^{27}$ Marín PAdILLA, «La villa de Arándiga», págs. 106-107. Un homónimo (quizás, él mismo), Jehudá Carrillo asistía en enero de 1444 a una reunión junto a un nutrido grupo de judíos, cristianos y mudéjares, para vender unos censos al converso zaragozano Gonzalvo de la Caballería (ibíd., pág. 86).

${ }^{28}$ Véase Fritz BAER, Die Juden im christlichen Spanien. Vol. I. Urkunden und Regesten. Aragonien und Navarra (Berlin 1929), docs. 523 (y anotaciones en pág. 841) y 531. 
35. Costantí, Salamó. Judío de Belchite (1425). Testigo en acto notarial en Belchite (25, 26 y $27-X I-1425$, f. $^{\circ} 204 \mathrm{r}$ y $\left.205 \mathrm{v}\right)$. Posiblemente se trata del discípulo del médico (y filósofo) rabí Senior, ya mencionado, del que debería recibir en 1439 parte de sus libros, según disposición de últimas voluntades ${ }^{29}$.

36. Elçahal, Juce. Judío de Belchite (1423). Testigo en acto notarial en Belchite (2-III-1423, f. ${ }^{\text {7 }}$ 7r).

37. Elisá, Jucé. Judío de Luna (1422-1423). Confesaba tener en comanda de Federico de Aragón, conde de Luna, 5.000 florines, en un acto realizado en Luna (27-XII-1422, f. ${ }^{\circ}$ 58r). Elisá fue nombrado por Mateu Pujades, procurador para recuperar las cantidades aparentemente entregadas en comanda por Pujades a diversas personas -a Martí de Fuentes, notario de Luna, 58 florines, a Guillem Jordán, de Luna, 40 florines, y a Martí de Borau, de Luna, 140 florines-, en un acto realizado en Luna. En documentos previos, dichos vecinos habían reconocido tener esas cantidades en depósito (5-II-1423, f. ${ }^{\circ}$ 63r), véase adelante, doc. n. ${ }^{\circ}$ 3. Mateu Pujades, caballero ciudadano de Valencia, había sido financiero del infante Martín y de su mujer, cuando eran aún condes de Luna, y estos le habían entregado la bailía general del reino de Valencia cuando fueron reyes ${ }^{30}$. Elisá aparece

${ }^{29}$ Cf. Minervini, Testi giudeospagnoli medievali, vol. I, pág. 263.

${ }^{30}$ La relación de Pujades con el conde de Luna se muestra en el manuscrito de Segorbe mediante distintos oficios: consiliari, comisari, administrador de las pecunias, olim administrans peccunias. En el testamento del conde se le asignan 5.000 florines de oro, más otros 2.000 de gracia para contraer matrimonio (13-VIII-1423, Barcelona). Como comisario del conde aparece actuando en La Pobla Vallbona (30-V-1421, mayo 30). Realiza la subasta de unos bienes de un mudéjar difunto de dicho lugar, indicándose que es «diputato dividendum et vendendum bona quorumdam saracenorum mortuorum in dicto loco» (8 y 14-VII-1421, Benaguasil). Reconoce haber recibido de Bernat Medina, receptor general del conde en el reino de Valencia, 4.000 ss de los pasados meses de noviembre y diciembre correspondientes al gasto ordinario de la casa del conde (30-III-1422, Valencia). Reconoce que Açach Avendino le había entregado, por orden del conde, 200 florines de los 2.000 que, en ayuda de los gastos de su matrimonio, le había prometido, según carta dada en Massamagrell el 1 de septiembre de 1422 (20-VI-1424, Barcelona). Al margen de los datos del manuscrito, con posterioridad a su relación con Federico de Aragón, sabemos que Pujades mantuvo una estrecha relación con la monarquía, siendo nombrado en octubre de 1436 receptor general con competencias para recaudar los donativos de las Cortes aragonesas, valencianas y catalanas, así como los derechos reales cobrados por los bailes generales. En noviembre de 1437 se le otorga licencia para aceptar letras de cambio, obtener préstamos, cargas censales y enajenar bienes del real Patrimonio y en junio de 1439, el rey lo designa tesorero, siendo el responsable máximo de la contabilidad de los estados de la confederación, falleciendo a fines de 1447, mencionándose a su hijo y heredero homónimo, cf. Felipe MAteu Llopis, «Algunos 
también mencionado como testigo en un acto notarial en Belchite (23-IV1423 , f. ${ }^{\circ} 81$ r).

38. Francés, Açach. Judío de Arándiga (1423-1432). Junto a Jafudá Cariello, también de Arándiga, se obligan en Belchite en pagar al receptor del conde de Luna 800 florines (sin especificación), si bien Cariello dice a continuación que la deuda sólo le atañía a él, y no a Açach (12-IV-1423, f. ${ }^{\circ}$ 80r). Açach Avendino, receptor del conde de Luna, reconocía que Francés, arrendador de las rentas del conde en el lugar de Arándiga, en relación a aquellos 1.900 ss jaqueses que Francés, junto a Jucé Azán, le habían de pagar el próximo 1 de mayo del precio del arriendo, le han entregado anticipados $1.500 \mathrm{ss}$, a saber 1.000 en contante y 500 ss en prorrata de los 2.000 ss pertenecientes a la pecha de dos años, en paga y satisfacción de los 2.000 ss que habían prestado al señor conde por «el passatge de Nàpols que fizo en el mes de agosto mas cerca passado» (24-II-1424, f. ${ }^{\text {o } 116 r) . ~ J u n t o ~ a ~ s u ~ e s p o s a ~ C a r a v i d a, ~ j u r a n ~ t e n e r ~ e n ~ p u r o ~ d e p o ́ s i t o ~}$ y comanda del conde de Luna 3.000 florines. El acto se realiza en Arándiga. En el documento aparece su signatura en hebreo (6-XI-1425, f. ${ }^{\circ}$ 200v) (fig. 2). Fue interrogado en el castillo de Arándiga como testigo sobre el robo de una serie de monedas perpetrado por Pedro de Huesa, en el hostal de Arándiga (7-XI-1425, folio suelto). En agosto de 1432, Açach, que «soliays estar e habitar en el lugar mio de Arándiga», recibió licencia de Juan Martínez de Luna, ahora señor de dicho lugar, para que «podades estar e seyer vassallo del senyor rey allá do a vos plazerá e bien visto será, con vuestra familia e companya», pudiendo sin ningún problema, recibir y administrar sus bienes en Arándiga ${ }^{31}$.

39. Gallur, Zecrí. Judío de Zaragoza (1423) ${ }^{32}$. Véase Açach Avendino.

40. Gotina, Nahamén. Judío de Zaragoza (1425). Testigo en acto notarial realizado en Belchite (21-XI-1425, f. ${ }^{\circ}$ 202v).

41. Nagerés, Mossé. Judío de Zaragoza (1423); véase Açach Avendino.

documentos referentes a la gestión del tesorero de Alfonso V, Mateo Pujades, y el itinerario del rey (1441-1447)», Hispania 3 (1941), págs. 3-31; David Igual Luís, «Entre Valencia y Nápoles. Banca y hombres de negocios desde el reinado de Alfonso el Magnánimo», En la España Medieval 24 (2001), págs. 103-143; NAVARRo EsPinaCh - Igual Luís, La tesorería general y los banqueros de Alfonso Vel Magnánimo, págs. 51-52.

${ }^{31}$ Marín PADILla, «La villa de Arándiga», pág. 79.

${ }^{32}$ Posiblemente se trate de Zecrí Gallur, documentado en Zaragoza desde 1399, dedicado al comercio de paños, del que en septiembre de 1402 se mencionaban unas casas suyas «siquiere traperia», cf. BlaSCO MARTínEZ, «Judíos zaragozanos comerciantes», pág. 605, n. 229-230. 


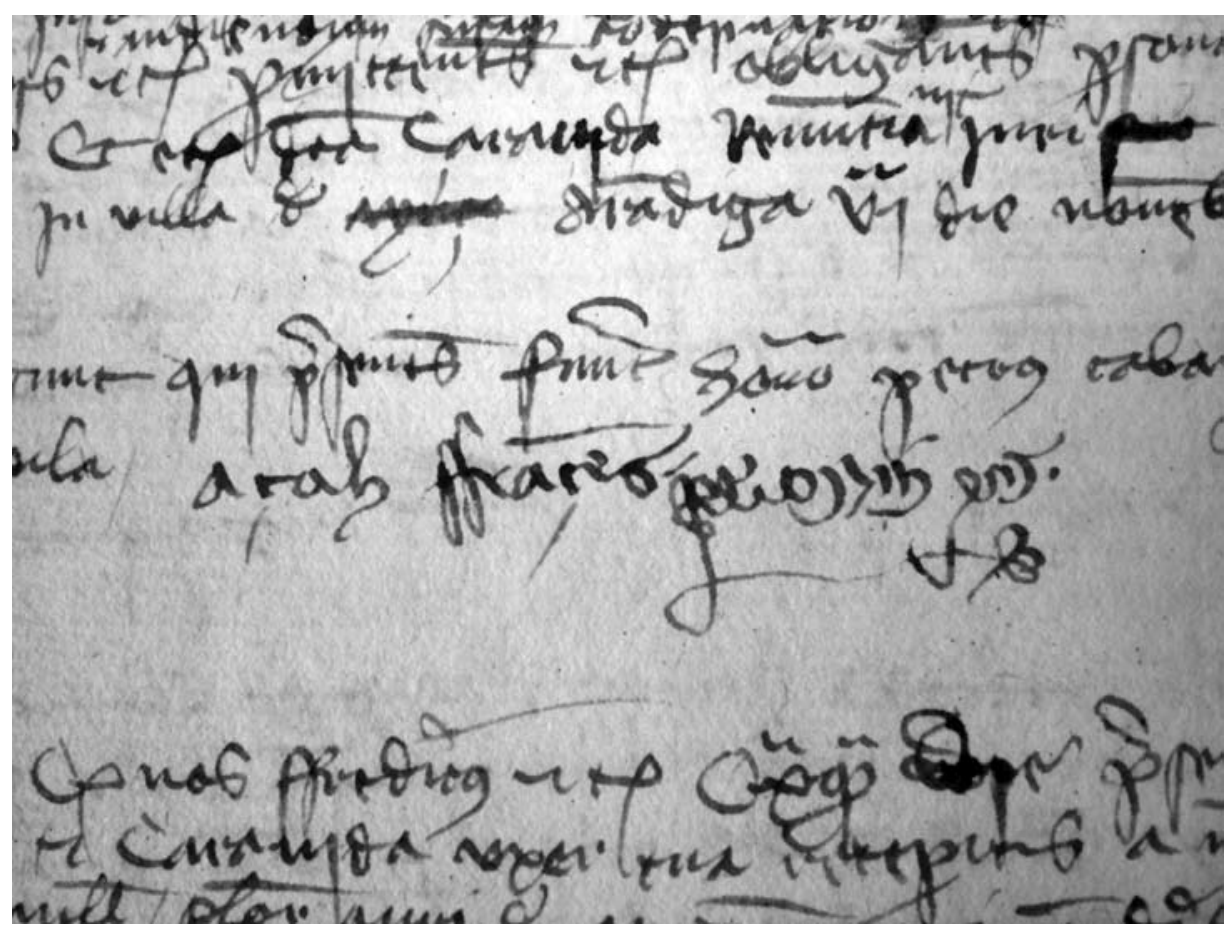

Fig. 2. Firma y rúbrica al pie de la comanda monetaria: «Açach Françés יצחק פראנסיש [rúbrica]» (f.o 200v).

42. ScalerA, Abraham. «Iudeus rabi aljame iudeorum dicte ville de Luna» (1422). Testigo en acto notarial en Luna (27-XII-1422, f. 58 r).

43. Xucrán / xocrán, Açach. Judío de Belchite (1423). Testigo en acto notarial en Belchite (2-III y 1-IV-1423, f. 71 r, 78v).

44. Xucrán, Mossé. Judío de Belchite (1425). Testigo en acto notarial en Belchite (27-XI-1425, f. 205v). 


\section{DOCUMENTOS}

\section{1}

1422, abril 28. Castillo de Burjassot

Açach Avendino, judío de Belchite, acepta la Receptoría General del condado de Luna en Aragón (f. $49 r-v)$.

Capítols sobre la receptoria d'Aragó.

Noverint universi, quod die martis intitulata XXVIII mensis aprilis, anno a Nativitate Domini $\mathrm{M}^{\circ} \mathrm{CCCCXXII}^{\circ}$, multum egregio et potenti viro domino Frederico de Aragone, comite de Luna, in castro loci de Burjaçot, personaliter existents, comparens coram eo Azach Abendino, judeus ville de Belxit, receptor generalis prefati domini comitis in comitatu de Luna regni Aragone, qui vocato ab hec me Pero de Cap de Vila, secretario dicti domini comitis et regia auctoritate notario publico per totam terram et dominacionem serenissimi domini regis Aragone ac testibus infrascriptis obtulit jamdicto domino comiti quedam capitula huius seriei:

A la gran senyoria de vós, molt alt senyor don Fredrich d'Aragó comte de Luna, offer Azach Abendino, juheu de la vostra vila de Belxit situada en Regne d'Aragó, los capítols deiús scrits, supplicant que sia vostra mercé benignament acceptar aquells e provehir-los segons sa convinència, e són aquests:

Primerament, que pus vós molt alt senyor volets e mantas que Azach Abendino regesca lo offici de vostra receptoria general en vostre comtat de Luna dins regne d'Aragó $^{33}$ supplica-us que sia vostra mercé provehir-li ab degut effecte que no pusca per vós senyor, ne per algun official vostre, ésser compellit a pagar o bistraure alguna cosa de ço del seu propri, sino tansolament allò que rebrà per rahó del dit offici, açò encara ajustat que si al dit Açach Abendino per sa plana voluntat res hi bestraurà, que allò se puxa retenir vers si, e pagar-se dels primers diners que de allí avant li vendran en son poder per rahó del dit offici. Plau al senyor comte.

Ítem, que sia mercé de vós senyor, atorgar e provehir al dit Azach Abendino que ell no sia tengut en altre loch retre los comptes del dit seu offici sino en les viles vostres de Belxit o de Huesa del dit comtat, o en la ciutat de Çaragoça, en poder de aquellas persona o personas que vostra senyoria elegirà, ab poder emperò bastant de hoyr, examinar e difinir los dits comptes, observant-hi en totes coses e per totes l'estil, pràtica e consuetut del offici de maestre racional del senyor rey. Plau al senyor comte.

Ítem, per major enlestiment e clarificació dels fets, sia mercé de vós senyor provheir e manar que finit cascun any, al dit Azach Abendino sia hoyt son compte

\footnotetext{
${ }^{33}$ Duplicado y tachado: «regne d'Aragó».
} 
del dit offici, lo qual ell se offer donar dins dos mesos aprés fi de cascun any. Plau al senyor comte.

Ítem, senyor que si s'esdevendrà cars que vós provehiscats a altre del dit offici, que en aquell cars lo dit Azach no puxa ésser tret del exercici del dit offici, ne ésser despullat del regiment de aquell, ne puxa per vós senyor ne per alguns officials vostres ésser inhibit, ne manat a vostres universitats e vassalls ne a altres persones qui haien res a pagar de vostres fruyts, rendes e drets que non responguen al dit Azach, ans si de fet los dits manaments o inhibicions se fahien sien nulls ipso facto. Et per no observar aquells e aquelles no puxen encòrrer les dites univeristats vasalls e altres en penes algunes tro que-ls comptes del temps que haurà regit e administrat lo dit offici lo dessús dit Azac sien stats hoyts, examinats e difinits ab observació dels damunt dits stil, pràtica e consuetut del dit offici de maestre racional. Et encara tro que-1 dit Azach Abendino sia estat pagat, reintegrat e satisfet si de res serà e de tant quant se mostrarà deure ésser retrobador per just compte, si dons lo dit Azach no era en mora o triga de retre los dits comptes ab compliment de legítimes cauteles. Plau al senyor comte.

Ítem, senyor que si per ventura lo dit Azach Abendino durant lo regiment seu e adminstració del dit offici morrà, que sia mercé vostra atorgar, provehir e manar que en aquell cars per mort sua no sien emparats o seqüestrats sos béns en alguna manera pus vós senyor siats en segur \| d'alló que per rahó del dit offici haurà rebut lo dit Azach. Et pus sos hereus, dins dos meses primers vinents aprés sa mort, haien fet retiment dels comptes ab compliment de cauteles de, e per aquell temps que-1 dit Açach de sa vida no serà stat diffinit segons los dits stil, pràtica e consuetut del dit maestre racional. Et que si en altra manera en emparar e seqüestrar hi serà contrafet, que les dites empares o seqüestracions sien nulles. Et que per no observar aquelles los dits hereus o altres persones e officials no puxen encòrrer en pena alguna. Plau al senyor comte.

Ítem, que vós senyor per major stabilitat de totes les dites coses e sengles per vostra mercé façats sagrament de observar aquelles. Plau al senyor comte de mentres que 1 dit Açach Abendino e sos hereus seran sos vassalls.

Ítem, humiliter supplicatio ut capitula preinserta que per dictum dominum comitem et in eius consilio jam [fuerunt] recognita et examinata jucare atque firmare digraretur. Et dictus eggregius dominus comes visis et recognitis ut dixit capitulis preinsertis juravit in posse notario subscriti per dominum Deum et eius sancta quattuor evangelia manibus suis corporaliter tacta capitula preinserta et omnia ac singula in eius et quolibet ipsorum contenta et expecificata iuxta responsiones dictis capitulis et [uniciuque] ipsorum factas tenere firmiter et servare tenerique et servari facere per quoscumque et non contrafacere vel venire nec aliquem contravenire permitere aliqua racione, jure sive cause de quibus dictus Açach ibidem presents requisuit me, dictus notario ut de predictis sibi confiterem publicum seu publica instrumenta tot quot inde habere voluerit ac habendum memoriam in futurum. Presentibus per testibus honorabiles Johanne de Sancto Felice, procura- 
tore generali in Regno Valencie dicti domini comitis, et Galcerando de Sancto Felice, militibus; Martinus de Comabella, canonico sugubricen et Matheo de Rada, presbitero dicte divitate Sugurbii, consiliaris jamdicti domini comitis. Et illo eodem instanti, dictus Açach Abendino, receptor generalis qui supra mandato dicti domini comitis juravit per dominum Deum et decem precepta legis Moyse ad modum judeorum tenere firmiter et servare capitula concordata facta atque firmata inter dictum dominum comitem parte ex una et homines habitantes in dicto comitatu de Luna ex altera, in et super quitamento et luicione factis atque fiendis de redditibus et juribus dicti comitatus durante tempore dictorum capitulorum et contra dicta capitula non facere vel venire aliqua racione, jure seu causa. Que fuerit acta die, anno et loco prefixis, presentibus per testibus proxime dictis et Mahir Abnuba, judeo ville de Belxit.

2

1422, octubre 26. [Pedrola]

Jucé Alcastiell, judio de Pedrola, ofrece fianza para que Bitas Abinforma no siguiera estando retenido por el conde de Luna ( $f^{o}$ 53r).

Die lune, XXVI octobris, anni predicti. Juce Alcastiell judeus loci de Pedrola manulevavit de posse dicto domini comitis in qua captus retinebat Bitas Abinforma filium de Salamo Abinforma, et promisit et se obligavit quod infra III dies proxime venturos satisfaciet integre a Salamo Abencanyes alio quod ipso debet dictum captum vel solvet quantitatem pro quo obligavit omnia bona sua, et dictus Bitas imposuit sibi de pena ni si compleriter predicta decem florines auri de Aragone, et cetera, ordinandam et cetera.

Testes fuerunt presentes venerabile Alfonsus de Daroca vicinus dicti loci, et Jahuda Abenaçot, ebreus dicti loci.

3

1423, febrero 5. Luna

Mateu Pujades, caballero de Valencia, nombra procurador a Jucé Elisá, judío de Luna, para recuperar ciertas cantidades $\left(f^{\circ} 63 r\right)$.

Dictis die et anno, in villa predicta de Luna. Honorabile Matheus Pujades, miles civitatis Valencie scienter citra revocavit et cetera, et constituit procuratorem suum Juceffum Elisa, judeum dicte ville de Luna, presentem, ad petendum pro eo et nomine 
suo, et habendum a Guillermus Jordani habitatore dicte ville XL florines, a Martino de Borau, centum quadragintam florines dicti auri, et a Martino de Fuentes quinquaginta et octo florines auri jamdicti et cetera, et de his que recepit apocas, [fines] et absoluciones, faciendum et firmandum et [...] ad destribuendum dictas peccunias pro ut sibi fuerit traditum in mandatis. Et generaliter ad faciendum omnia alia et cetera. Promitens et cetera. Obligavit et cetera.

Testes fuerunt presentes venerabiles Sancius Martini de Ladron, justicia dicte ville, et Martinus de Luna, porterius domini comitis.

\section{4}

\section{5, octubre 15. Bureta}

Los jurados mudéjares de Bureta reconocen que Jucé Axeuill, judío de Borja, rearrendador de las rentas del conde en Bureta, les ha entregado 2.100 sueldos por la paga de octubre (f. $\left.{ }^{\circ} 200 r\right)$.

Sepan todos que nós, Mahomat el Ferrero, Mahomat Cançala, alias Carnicero, Jucé Borxact e Abdallá Obeix, jurados del lugar de Brueta ${ }^{34}$, de cierta sciencia confessamos e en verdat recognoscemos a vos, Jucé Açevill, judío de la villa de Borja, re-arrendador de las rendas al senyor comte de Luna pertenescientes en el dito lugar de Brueta, que por la tanda e paga del present mes de octubre nos havedes dados e pagados dos mill e cient sueldos jaquesos en aquesta manera, y•es a saber, en dineros comptantes en presencia de los notario e testimonios diús scriptos, mil nouçientos e vint sueldos. Et en taras del molino farinero por vos, mediant sagrament adveradas con cinquo florines d'oro d'Aragón que diestes de senyal por una muela que comprastes por al dito molino, cient huytanta sueldos de la dita moneda, que montan la dita suma de IImilia C sueldos. Et por tal como assín y•es el feyto de la verdat que de los ditos IImilia C sueldos por vós, a nós dados e pagados segunt dito y•es, nos tenemos por bien contentos e pagados, e la nuestra voluntat façemos-vos ende la present ápoca en testimonio de las ditas cosas. Actum est hoc in loco de Brueta, XV die octobris, anno a Nativitate Domini $\mathrm{M}^{\circ} \mathrm{CCCCXXV}^{\circ}$. Sen++++yals de nós, ditos Mahomat el Ferrero, Mahomat Cançala, Jucé Borxact e Abdallá Obeix, jurados del dito lugar de Brueta ${ }^{35}$ qui las ditas cosas atorgamos e firmamos.

Testimonios fueron presentes a las ditas cosas el honrado Martín d'Aynçón, alcayde de Aynçón, Zecrí Abenabez, judío de Belxit, e Mahomat lo Pellón, moro del dito lugar de Brueta.

\footnotetext{
${ }^{34}$ Tachado: «Confes».

${ }^{35}$ Sobre línea: «de Brueta».
} 
1425, noviembre 8. Arándiga

Luna Cohena reconoce tener en comanda o puro depósito del conde de Luna, 500 florines de oro $\left(f^{\circ}{ }^{2} 201 r\right)$.

Die VIII novembris, anno predicto MCCCCXXV, in villa de Arandiga. Luna Cohena muller que fou de Rabí Abraham Benbaca, de certa sciència confessa ab aquesta present pública carta per tots temps valedera tenere en pura comanda e plan depòsit del eggregio senyor don Fredrich d'Aragó, comte de Luna, cinchcens florins d'or d'Aragó de bon pes, perquè renuncia a excepció de la dita quantitat non contada, et en si rebuda, e a excepció de enganyo. Et promés restituir la dita comanda tota vegada que·n seria requesta sens scusació e dilació alguna, prometent que si per haber e cobrar la dita comanda o partida de aquella messions o dampnatges alguns sostenia o fahia, aquells li promés pagar entegrament, de sos béns et pagues ésser feta execució per aquell jutge que elgiria al for e jurisdicció del qual se sotsmés, e renuncia a son propri for et cetera. Et per tenir e complir las ditas cosas obliga sa persona e tots sos béns mobles e sehents. Et renuncia et cetera. Et no res menys, constituí procuradors seus a $n$ Jacme de Castro e Pere Aznárez de Soteros, absents axí com si fossen presents, abdós ensemps e cascú per si, en axí que no sia millor la condició et cetera, és a saber a confessar la dita comanda e hoyr condempnació de aquella devant lo justícia d'Aragó o altre official et cetera. Et promés haver per firme et cetera, sots obligació de tots sos béns e quod ordinetur largo modo et cetera.

Testimonis foren presents Martín d'Ambell, vehí d'Aràndiga e Jahudá Cariello.

Et illo eodem instanti dictus dominus comes concessit atque mandavit notario predicta reciperunt quod predictum instrumentum non extrahatur aliquo modo in forma ni si causa quod dicta Luna se absentaret a dominacionem dicti domini comitis cum sit esset deductum in pactum ordinandam largo modo et cetera. Testes fuerunt superius proxime dictus.

Recibido: $25 / 09 / 2010$

Aceptado: 09/02/2011 